\title{
Preparation of Antibacterial Polymer-Grafted Silica Nanoparticle and Surface Properties of Composites Filled with the Silica (2)
}

\author{
By Takashi KaWAHARA, ${ }^{1}$ Yoko TAKEUCHI, ${ }^{1}$ Gang WEI, ${ }^{2}$ Kumi SHIRAI, ${ }^{3}$ \\ Takeshi YAMAUCHI, ${ }^{1,2,4}$ and Norio TSUBOKAWA ${ }^{1,2,4, *}$
}

\begin{abstract}
Antibacterial polymer was grafted onto silica nanoparticle and the surface properties of various composites filled with the silica were investigated. The grafting of antibacterial polymer, poly(vinylbenzyltributylphosphonium chloride) (poly(St$\mathrm{CH}_{2} \mathrm{P}^{+}(\mathrm{Bu})_{3} \mathrm{Cl}^{-}$)), onto silica surface was achieved by two methods: one is treatment of poly(vinylbenzylchloride) (poly(St$\mathrm{CH}_{2} \mathrm{Cl}$ ))-grafted silica with tributylphosphine and the other is direct grafting of poly $\left(\mathrm{St}_{-}-\mathrm{CH}_{2} \mathrm{P}^{+}\left(\mathrm{Bu}_{3} \mathrm{Cl}^{-}\right)\right.$by radical graft polymerization of the corresponding monomer. The grafting of poly $\left(\mathrm{St}_{-}-\mathrm{CH}_{2} \mathrm{Cl}\right)$ and poly $\left(\mathrm{St}_{-}-\mathrm{CH}_{2} \mathrm{P}^{+}(\mathrm{Bu})_{3} \mathrm{Cl}^{-}\right)$onto silica surface were initiated by the system consisting of trichloroacetyl groups on the silica surface and $\mathrm{Mo}(\mathrm{CO})_{6}$. Trichloroacetyl groups were introduced onto the silica surface by the reaction of amino groups on the silica surface with trichloroacetyl isocyanate. The percentage of poly $\left(\mathrm{St}_{-}-\mathrm{CH}_{2} \mathrm{Cl}\right)$ grafting during the graft polymerization initiated by the system increased with progress of the polymerization reached $116 \%$. The grafting of poly $\left(\mathrm{St}_{-}-\mathrm{CH}_{2} \mathrm{P}^{+}\left(\mathrm{Bu}_{3} \mathrm{Cl}^{-}\right)\right.$onto silica surfaces was confirmed by FT-IR spectra, thermal decomposition gas chromatograms and mass spectra (GC-MS), and ${ }^{13} \mathrm{C}-\mathrm{CP} / \mathrm{MAS}$ NMR. The surfaces of silicone rubber, polystyrene film, and paints filled with the poly $\left(\mathrm{St}_{-}-\mathrm{CH}_{2} \mathrm{P}^{+}(\mathrm{Bu})_{3} \mathrm{Cl}^{-}\right)$-grafted silica shows strong antibacterial activity. These composites retained the antibacterial activity even after the boiling in water for $24 \mathrm{~h}$.

KEY WORDS: Silica Nanoparticle / Surface Grafting of Polymer / Antibacterial Polymer / Tributylphosphonium Group / Antibacterial

Surface / Silicone Rubber /
\end{abstract}

Many researchers have extensively studied the chemical and physical modifications of nanoparticle surfaces. Among the permanent chemical modifications, the surface grafting of polymers, namely, chemical binding of polymers onto silica nanoparticles interests us for use in designing new functional inorganic/organic hybrid materials, which have excellent properties both of inorganic materials, such as heat-resistance and chemical-resistance, and of grafted polymers, such as photosensitivity, curing ability, bioactivity, biocompatibility, and pharmacological activities. ${ }^{1-6}$ For example, we have reported that a capsaicin-immobilized silica shows biorepellent activity. ${ }^{6}$

In our previous work, we have reported that the system consisting of $\mathrm{Mo}(\mathrm{CO})_{6}$ and surface trichloroacetyl groups on nanoparticles, such as silica ${ }^{7}$ and vapor grown carbon fiber (VGCF), ${ }^{8}$ has an ability to initiate the radical polymerization of various vinyl monomers to give the corresponding polymergrafted silica and VGCF. We pointed out that the effective radical grafting was achieved in the initiating system consisting of trichloroacetyl groups and $\mathrm{Mo}(\mathrm{CO})_{6}$, and percentage of grafting exceeded $200 \%$ because of no formation of fragment radicals. ${ }^{7,8}$

On the other hand, various kinds of antibacterial polymers were reported. ${ }^{9-11}$ For example, alkylphosphonium polymers show extremely strong antibacterial activity to Escherichia coli and Staphylococcus aureus. In the previous paper, we have succeeded in the grafting of polymer having alkylphosphonium sulfate groups $\left(\operatorname{poly}\left(\mathrm{St}_{-} \mathrm{SO}_{3}{ }^{-} \mathrm{P}^{+}(\mathrm{Bu})_{3} \mathrm{R}\right)\right)$ onto the surface of silica nanoparticle. ${ }^{12} \mathrm{We}$ have pointed out that the surface of silicone rubber filled with the poly $\left(\mathrm{St}_{-} \mathrm{SO}_{3}{ }^{-} \mathrm{P}^{+}(\mathrm{Bu})_{3} \mathrm{R}\right)$-grafted silica shows strong antibacterial activity to a Staphylococcus aureus and an Escherichia coli.

In this paper, the radical grafting of poly(vinylbenzyltributylphosphonium chloride) (poly $\left(\mathrm{St}-\mathrm{CH}_{2} \mathrm{P}^{+}\left(\mathrm{Bu}_{3} \mathrm{Cl}^{-}\right)\right.$) onto silica surface. The grafting of poly $\left(\mathrm{St}-\mathrm{CH}_{2} \mathrm{P}^{+}\left(\mathrm{Bu}_{3} \mathrm{Cl}^{-}\right)\right.$was achieved by two methods: one is treatment of poly(vinylbenzylchloride) (poly $\left.\left(\mathrm{St}-\mathrm{CH}_{2} \mathrm{Cl}\right)\right)$-grafted silica with tributylphosphine (Scheme 1) and the other is direct grafting of poly $\left(\mathrm{St}-\mathrm{CH}_{2} \mathrm{P}^{+}(\mathrm{Bu})_{3} \mathrm{Cl}^{-}\right)$by radical graft polymerization of the corresponding monomer (Scheme 2). In addition, the antibacterial activity of the surfaces of composites prepared from the poly $\left(\mathrm{St}-\mathrm{CH}_{2} \mathrm{P}^{+}(\mathrm{Bu})_{3} \mathrm{Cl}^{-}\right)$-grafted silica will be discussed.

\section{EXPERIMENTAL}

\section{Materials and Reagents}

Silica nanoparticle used was obtained from Nippon Aerosil Co., Ltd., Japan. The specific surface area, average particle size, and silanol group content were $200 \mathrm{~m}^{2} / \mathrm{g}, 12 \mathrm{~nm}$, and $1.37 \mathrm{mmol} / \mathrm{g}$, respectively. The silica was dried in vacuo at $40^{\circ} \mathrm{C}$ for $24 \mathrm{~h}$ before use.

\footnotetext{
${ }^{1}$ Graduate School of Science and Technology, Niigata University, 8050, Ikarashi 2-no-cho, Nishi-ku, Niigata 950-2181, Japan

${ }^{2}$ Niigata University Venture Business Laboratory, 8050, Ikarashi 2-no-cho, Nishi-ku, Niigata 950-2181, Japan

${ }^{3}$ Department of Material Science and Technology, Faculty of Engineering, Niigata University, 8050, Ikarashi 2-no-cho, Nishi-ku, Niigata 950-2181, Japan

${ }^{4}$ Center for Transdisciplinary Research, Niigata University, 8050, Ikarashi 2-no-cho, Nishi-ku, Niigata 950-2181, Japan

*To whom correspondence should be addressed (Tel/Fax: +81-25-262-6779, E-mail: ntsuboka@eng.niigata-u.ac.jp).
} 

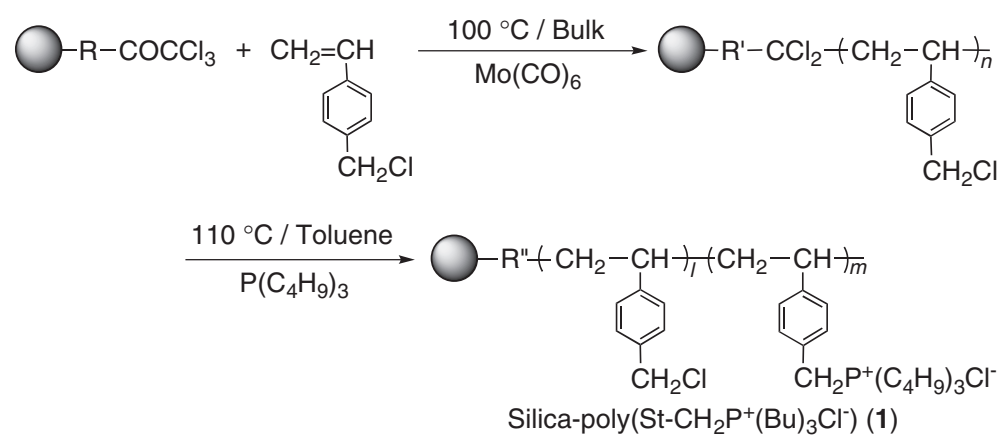

Scheme 1. Preparation of Silica-poly $\left(\mathrm{St}-\mathrm{CH}_{2} \mathrm{P}^{+}(\mathrm{Bu})_{3} \mathrm{Cl}^{-}\right)(\mathbf{1})$ by two-step reaction.
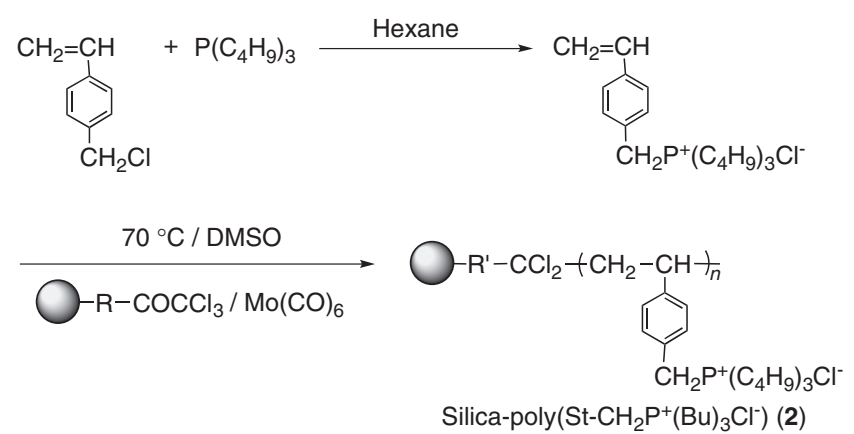

Scheme 2. Preparation of Silica-poly $\left(\mathrm{St}-\mathrm{CH}_{2} \mathrm{P}^{+}(\mathrm{Bu})_{3} \mathrm{Cl}^{-}\right)(2)$ by direct graft polymerization of St- $\mathrm{CH}_{2} \mathrm{P}^{+}(\mathrm{Bu})_{3} \mathrm{Cl}^{-}$.

4-Vinylbenzylchloride $\left(\mathrm{St}-\mathrm{CH}_{2} \mathrm{Cl}\right)$ obtained from SigmaAldrich Co., Ltd. was distilled under reduced pressure. Trichloroacetyl isocyanate, molybdenum hexacarbonyl $\left(\mathrm{Mo}(\mathrm{CO})_{6}\right)$, and tributylphosphine obtained from Kanto Chemical Co., Inc., Japan were used without further purification. Dimethyl sulfoxide (DMSO) obtained from Kanto Chemical Co., Inc., Japan was distilled before use. Dehydrated toluene and tetrahydrofuran (THF) were obtained from Kanto Chemical Co., Inc., Japan and used without further purification.

\section{Silicone Rubber, Polystyrene, and Paints}

Silicone rubber, poly(dimethylsiloxane), (two-component type) was obtained from Shin-Etsu Chemical Co., Ltd., Japan. Polystyrene was obtained from Wako Pure Chemical Industries, Ltd., Japan and used without further purification. Water paint (Neogloss G-80; acrylic emulsion type) and oil paint (Neopaint urethane \#5500AB; two-component acrylic urethane type) were obtained from Asia Industry Co., Ltd., Japan.

\section{Preparation of St- $\mathrm{CH}_{2} \mathrm{P}^{+}(\mathrm{Bu})_{3} \mathrm{Cl}^{-}$}

St- $\mathrm{CH}_{2} \mathrm{P}^{+}(\mathrm{Bu})_{3} \mathrm{Cl}^{-}$was prepared by the reaction of St$\mathrm{CH}_{2} \mathrm{Cl}$ with tributylphosphine according to the method of literature. ${ }^{11}$ The structure of $\mathrm{St}-\mathrm{CH}_{2} \mathrm{P}^{+}(\mathrm{Bu})_{3} \mathrm{Cl}^{-}$was confirmed by FT-IR, ${ }^{1} \mathrm{H} \mathrm{NMR}$, and ${ }^{13} \mathrm{C} \mathrm{NMR}$.

\section{Introduction of Trichloroacetyl Groups onto Silica Nano- particle}

The introduction of trichloroacetyl groups onto silica nanoparticle surface was achieved by the reaction of trichloroacetyl isocyanate with amino groups on the silica surface. ${ }^{7}$ The treated silica was abbreviated as Silica- $\mathrm{COCCl}_{3}$.

\section{Preparation of Silica-poly $\left(\mathrm{St}-\mathrm{CH}_{2} \mathrm{P}^{+}\left(\mathrm{Bu}_{3} \mathrm{Cl}^{-}\right)\right.$(1) by Two- step Reaction}

The grafting of poly $\left(\mathrm{St}-\mathrm{CH}_{2} \mathrm{P}^{+}(\mathrm{Bu})_{3} \mathrm{Cl}^{-}\right)$was achieved by the treatment of poly $\left(\mathrm{St}-\mathrm{CH}_{2} \mathrm{Cl}\right)$-grafted silica with tributylphosphine as shown in Scheme 1. The radical graft polymerization of $\mathrm{St}-\mathrm{CH}_{2} \mathrm{Cl}$ initiated by the system consisting of Silica$\mathrm{COCCl}_{3}$ and $\mathrm{Mo}(\mathrm{CO})_{6}$ was carried out in a sealed tube under high vacuum. A typical example was as follows. Into a polymerization tube, $0.20 \mathrm{~g}$ of Silica- $\mathrm{COCCl}_{3}, 0.01 \mathrm{~g}$ of $\mathrm{Mo}(\mathrm{CO})_{6}, 5.0 \mathrm{~mL}$ of $\mathrm{St}-\mathrm{CH}_{2} \mathrm{Cl}$, and a stirrer bar were charged. The mixture was frozen in a liquid nitrogen bath, degassed with a high vacuum pump, and then thawed. After this operation was repeated three times, the tube was heated at $100^{\circ} \mathrm{C}$ with stirring. After the reaction, the product was dispersed in THF and centrifuged. The supernatant solution was removed and precipitated silica was dispersed again in THF. The procedures were repeated until no more ungrafted polymer could be detected in the supernatant solution. The resulting silica was abbreviated as Silica-poly $\left(\mathrm{St}-\mathrm{CH}_{2} \mathrm{Cl}\right)$.

The Silica-poly $\left(\mathrm{St}-\mathrm{CH}_{2} \mathrm{Cl}\right)$ was treated with tributylphosphine to convert the benzylchloride groups to tributylphosphonium groups. ${ }^{11} \mathrm{~A}$ typical example was as follows. $1.0 \mathrm{~g}$ of Silica-poly $\left(\mathrm{St}-\mathrm{CH}_{2} \mathrm{Cl}\right)$ was charged into a three-necked flask attached with a reflux condenser, and then a mixture of $50.0 \mathrm{~mL}$ of toluene and $5.0 \mathrm{~mL}$ of tributylphosphine was dropped by a syringe into the flask under nitrogen. The reaction mixture was refluxed at $110^{\circ} \mathrm{C}$ with stirring for $24 \mathrm{~h}$. After the reaction, the product was dispersed in THF and centrifuged. The supernatant solution was removed and precipitated silica was dispersed again in THF. The procedures were repeated until no more tributylphosphine could be detected in the supernatant solution. The resulting silica was abbreviated as Silica-poly(St$\left.\mathrm{CH}_{2} \mathrm{P}^{+}(\mathrm{Bu})_{3} \mathrm{Cl}^{-}\right)(\mathbf{1})$.

Preparation of Silica-poly $\left(\mathrm{St}_{-} \mathrm{CH}_{2} \mathrm{P}^{+}\left(\mathrm{Bu}_{3} \mathrm{Cl}^{-}\right)\right.$(2) by Direct Graft Polymerization of St- $\mathrm{CH}_{2} \mathrm{P}^{+}(\mathrm{Bu})_{3} \mathrm{Cl}^{-}$

The direct graft polymerization of $\mathrm{St}_{-} \mathrm{CH}_{2} \mathrm{P}^{+}(\mathrm{Bu})_{3} \mathrm{Cl}^{-}$ initiated by the system consisting of Silica-COCCl${ }_{3}$ and $\mathrm{Mo}(\mathrm{CO})_{6}$ was carried out in a sealed tube under high vacuum. 


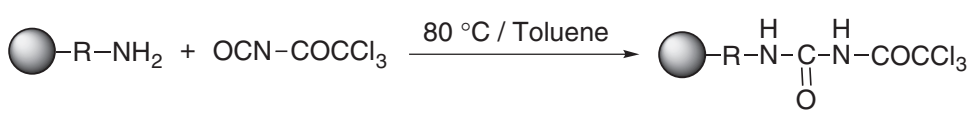

Scheme 3. Introduction of trichloroacetyl groups onto silica nanoparticle surface.

The graft polymerization was carried out by the same manner as grafting of poly $\left(\mathrm{St}-\mathrm{CH}_{2} \mathrm{Cl}\right)$ onto silica as mentioned above. The resulting silica was abbreviated as Silica-poly(St$\left.\mathrm{CH}_{2} \mathrm{P}^{+}(\mathrm{Bu})_{3} \mathrm{Cl}^{-}\right)(2)$.

\section{Percentage of Grafting}

The grafting of poly $\left(\mathrm{St}-\mathrm{CH}_{2} \mathrm{Cl}\right)$ and poly(St$\left.\mathrm{CH}_{2} \mathrm{P}^{+}(\mathrm{Bu})_{3} \mathrm{Cl}^{-}\right)$onto silica surface was determined by the following equation:

$$
\text { Grafting }(\%)=(A / B) \times 100
$$

where $A$ is weight of $\operatorname{poly}\left(\mathrm{St}-\mathrm{CH}_{2} \mathrm{Cl}\right)$ or poly(St$\left.\mathrm{CH}_{2} \mathrm{P}^{+}(\mathrm{Bu})_{3} \mathrm{Cl}^{-}\right)$grafted onto silica surface and $B$ is weight of silica used. $A$ was determined by measuring the weight loss when these polymer-grafted silica was heated at $800^{\circ} \mathrm{C}$ using a thermogravimetric analyzer (TGA) under nitrogen.

\section{Tributylphosphonium Group Content of Silica-poly(St- $\mathrm{CH}_{2} \mathrm{P}^{+}\left(\mathrm{Bu}_{3} \mathrm{Cl}^{-}\right)$(1)}

Tributylphosphonium group content of Silica-poly(St$\left.\mathrm{CH}_{2} \mathrm{P}^{+}(\mathrm{Bu})_{3} \mathrm{Cl}^{-}\right)(\mathbf{1})$ was calculated from the weight increment of Silica-poly $\left(\mathrm{St}-\mathrm{CH}_{2} \mathrm{Cl}\right)$ after the treatment with tributylphosphine determined by TGA as mentioned above.

\section{Measurements}

Thermogravimetric analysis (TGA) was performed under a nitrogen flow using a thermogravimetric analyzer (Shimadzu Manufacturing Co., Ltd., TGA-50) at a heating rate of $10^{\circ} \mathrm{C} /$ min. Infrared spectrum was recorded on a FT-IR spectrophotometer (Shimadzu Manufacturing Co., Ltd., FT-IR-8200A). Thermal decomposition gas chromatograms and mass spectra were recorded on a gas chromatograph mass spectrometer (GCMS) (Shimadzu Manufacturing Co., Ltd., GCMS-QP2010) equipped with a double shot pyrolyzer (Frontier Laboratories Ltd., PY-2020D). ${ }^{13} \mathrm{C}-\mathrm{CP} / \mathrm{MAS}$ NMR was recorded on a Bruker MSL-300.

\section{Preparation of Composites Filled with Silica-poly(St- $\left.\mathrm{CH}_{2} \mathrm{P}^{+}(\mathrm{Bu})_{3} \mathrm{Cl}^{-}\right)$}

Silica-poly $\left(\mathrm{St}-\mathrm{CH}_{2} \mathrm{P}^{+}(\mathrm{Bu})_{3} \mathrm{Cl}^{-}\right)$was uniformly dispersed in poly(dimethylsiloxane) containing a curing agent using a hybrid-deforming mixer (Thinky Co., AR-100) at room temperature. By heating the mixture at $70{ }^{\circ} \mathrm{C}$ for $20 \mathrm{~min}$, silicone rubber filled with Silica-poly $\left(\mathrm{St}-\mathrm{CH}_{2} \mathrm{P}^{+}(\mathrm{Bu})_{3} \mathrm{Cl}^{-}\right)$was obtained.

Polystyrene film filled with Silica-poly $\left(\mathrm{St}-\mathrm{CH}_{2} \mathrm{P}^{+}(\mathrm{Bu})_{3} \mathrm{Cl}^{-}\right)$ was prepared as follows. $10.0 \mathrm{~g}$ of polystyrene was dissolved in toluene. Then, $0.10 \mathrm{~g}$ of Silica-poly $\left(\mathrm{St}-\mathrm{CH}_{2} \mathrm{P}^{+}(\mathrm{Bu})_{3} \mathrm{Cl}^{-}\right)$was added into the solution and the mixture was stirred under irradiation of ultrasonic wave. The mixture was casted in a Petri dish and toluene was evaporated at room temperature.
Paints filled with Silica-poly $\left(\mathrm{St}-\mathrm{CH}_{2} \mathrm{P}^{+}(\mathrm{Bu})_{3} \mathrm{Cl}^{-}\right)$were prepared as follows. $0.1 \%$ of Silica-poly $\left(\mathrm{St}-\mathrm{CH}_{2} \mathrm{P}^{+}(\mathrm{Bu})_{3} \mathrm{Cl}^{-}\right)$ was mixed with a commercially available paint and curing agent using a hybrid deforming mixer. The mixture was painted on a Petri dish and dried at $50{ }^{\circ} \mathrm{C}$ for $24 \mathrm{~h}$.

\section{Assessment of Antibacterial Activity of the Composite Surfaces}

The surface antibacterial activity of the composites filled with Silica-poly $\left(\mathrm{St}-\mathrm{CH}_{2} \mathrm{P}^{+}(\mathrm{Bu})_{3} \mathrm{Cl}^{-}\right)$was estimated according to the method of the Japanese Industrial Standards (JIS Z 2801). The detailed procedures were described in our previous paper. $^{12}$

\section{RESULTS AND DISCUSSION}

\section{Introduction of Trichloroacetyl Groups onto Silica Nano- particle}

The introduction of trichloroacetyl groups onto silica surface by the reaction of trichloroacetyl isocyanate with amino groups on the silica surface was successfully achieved (Scheme 3). The content of trichloroacetyl groups introduced onto silica surface, which was determined from the unreacted amino groups, was $0.26 \mathrm{mmol} / \mathrm{g}$. The result suggests that about $90 \%$ of amino groups were successfully converter to trichloroacetyl groups.

\section{Preparation of Silica-poly $\left(\mathrm{St}-\mathrm{CH}_{2} \mathrm{P}^{+}\left(\mathrm{Bu}_{3} \mathrm{Cl}^{-}\right)\right.$(1) by Two- step Reaction}

Figure 1 shows the result of the grafting of poly $\left(\mathrm{St}-\mathrm{CH}_{2} \mathrm{Cl}\right)$ onto silica nanoparticle surface during the graft polymerization of $\mathrm{St}-\mathrm{CH}_{2} \mathrm{Cl}$ initiated by the system consisting of Silica$\mathrm{COCCl}_{3}$ and $\mathrm{Mo}(\mathrm{CO})_{6}$. No polymerization of $\mathrm{St}-\mathrm{CH}_{2} \mathrm{Cl}$ was initiated by the system consisting of untreated silica and $\mathrm{Mo}(\mathrm{CO})_{6}$. On the contrary, the graft polymerization of St$\mathrm{CH}_{2} \mathrm{Cl}$ was successfully initiated by the system consisting of $\mathrm{Silica}_{-} \mathrm{COCCl}_{3}$ and $\mathrm{Mo}(\mathrm{CO})_{6}$. The percentage of poly(St$\mathrm{CH}_{2} \mathrm{Cl}$ ) grafting onto the silica surface increased with progress of the polymerization and reached $116 \%$ after $6 \mathrm{~h}$.

To convert the benzylchloride groups of grafted chains on the silica to tributylphosphonium groups, Silica-poly(St$\mathrm{CH}_{2} \mathrm{Cl}$ ) was treated with tributylphosphine as shown in Scheme 1. Figure 2 shows FT-IR spectra of (A) Silica$\mathrm{COCCl}_{3}$, (B) Silica-poly $\left(\mathrm{St}-\mathrm{CH}_{2} \mathrm{Cl}\right)$, and (C) Silica-poly(St$\left.\mathrm{CH}_{2} \mathrm{P}^{+}(\mathrm{Bu})_{3} \mathrm{Cl}^{-}\right)$(1). FT-IR spectra of Silica-poly $\left(\mathrm{St}-\mathrm{CH}_{2} \mathrm{Cl}\right)$ show a new adsorption at $2930 \mathrm{~cm}^{-1}$, which is characteristic of methylene groups of poly $\left(\mathrm{St}-\mathrm{CH}_{2} \mathrm{Cl}\right)$. FT-IR spectra of Silica-poly $\left(\mathrm{St}_{-} \mathrm{CH}_{2} \mathrm{P}^{+}(\mathrm{Bu})_{3} \mathrm{Cl}^{-}\right)(\mathbf{1})$ show strong adsorptions at 2959-2872 $\mathrm{cm}^{-1}$, which are characteristic of alkyl chains of tributylphosphonium groups. Therefore, the results suggest that 


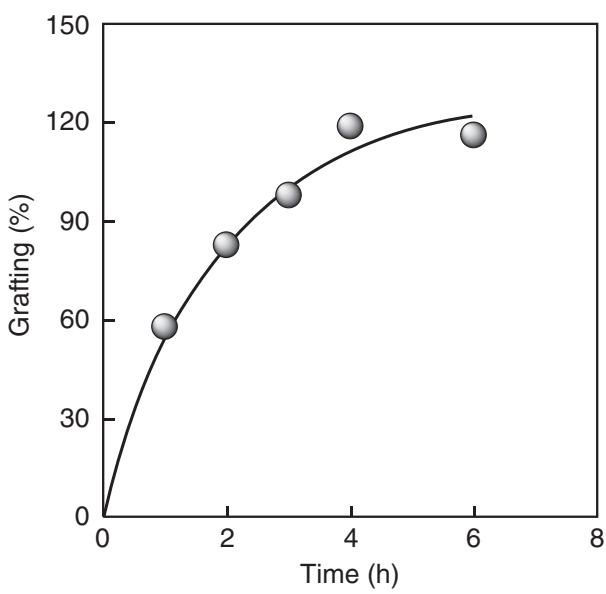

Figure 1. Grafting of poly $\left(\mathrm{St}-\mathrm{CH}_{2} \mathrm{Cl}\right)$ onto silica nanoparticle surface during the polymerization of $\mathrm{St}-\mathrm{CH}_{2} \mathrm{Cl}$ initiated by the system consisting of Silica- $\mathrm{COCCl}_{3}$ and $\mathrm{Mo}(\mathrm{CO})_{6}$. Silica- $\mathrm{COCCl}_{3}, 0.20 \mathrm{~g} ; \mathrm{Mo}(\mathrm{CO})_{6}$, $0.01 \mathrm{~g} ; \mathrm{St}-\mathrm{CH}_{2} \mathrm{Cl}, 5.0 \mathrm{~mL} ; 100^{\circ} \mathrm{C}$.

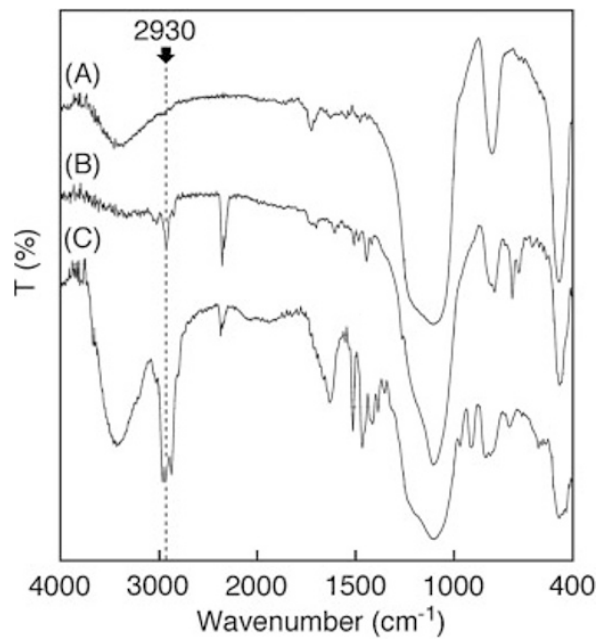

Figure 2. FT-IR spectra of (A) Silica- $\mathrm{COCCl}_{3}$, (B) Silica-poly $\left(\mathrm{St}-\mathrm{CH}_{2} \mathrm{Cl}\right)$, and (C) Silica-poly $\left(\mathrm{St}_{-} \mathrm{CH}_{2} \mathrm{P}^{+}(\mathrm{Bu})_{3} \mathrm{Cl}^{-}\right)(\mathbf{1})$.

poly $\left(\mathrm{St}_{-} \mathrm{CH}_{2} \mathrm{Cl}\right)$ grafted onto silica surface was successfully converted to poly $\left(\mathrm{St}_{-}-\mathrm{CH}_{2} \mathrm{P}^{+}(\mathrm{Bu})_{3} \mathrm{Cl}^{-}\right)$.

Figure 3 shows the thermal decomposition gas chromatograms and mass spectra (GC-MS) of (A) tributylphosphine and (B) Silica-poly $\left(\mathrm{St}_{-} \mathrm{CH}_{2} \mathrm{P}^{+}\left(\mathrm{Bu}_{3} \mathrm{Cl}^{-}\right)(\mathbf{1})\right.$. Mass spectra of decomposed gas of Silica-poly $\left(\mathrm{St}_{-} \mathrm{CH}_{2} \mathrm{P}^{+}\left(\mathrm{Bu}_{3} \mathrm{Cl}^{-}\right)(\mathbf{1})\right.$ at retention time $5.2 \mathrm{~min}$ was in agreement with those of tributylphosphine. Therefore, the result also shows that tributylphosphonium groups were introduced onto Silica-poly $\left(\mathrm{St}-\mathrm{CH}_{2} \mathrm{Cl}\right)$.

Figure 4 shows ${ }^{13} \mathrm{C}-\mathrm{CP} / \mathrm{MAS}$ NMR spectrum of Silicapoly $\left(\mathrm{St}_{-} \mathrm{CH}_{2} \mathrm{P}^{+}(\mathrm{Bu})_{3} \mathrm{Cl}^{-}\right)(\mathbf{1})$. The signals of carbon atoms based on poly $\left(\mathrm{St}_{-} \mathrm{CH}_{2} \mathrm{P}^{+}(\mathrm{Bu})_{3} \mathrm{Cl}^{-}\right)$were observed. The signal of carbon atoms based on benzylchloride groups, which did not reacted with tributylphosphine, were observed at $50 \mathrm{ppm}$.

Based on the above results, it is concluded that poly(St$\left.\mathrm{CH}_{2} \mathrm{P}^{+}(\mathrm{Bu})_{3} \mathrm{Cl}^{-}\right)$was successfully grafted onto silica surface. The percentage of benzylchloride groups reacted with tributylphosphine was determined to be about $70 \%$ by TGA.

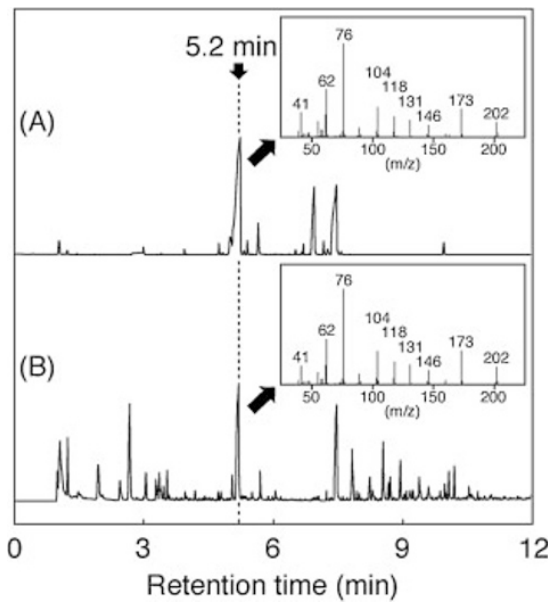

Figure 3. Thermal decomposition gas chromatograms and mass spectra (GC-MS) of (A) tributylphosphine and (B) Silica-poly(St$\left.\mathrm{CH}_{2} \mathrm{P}^{+}(\mathrm{Bu})_{3} \mathrm{Cl}^{-}\right)(\mathbf{1})$.

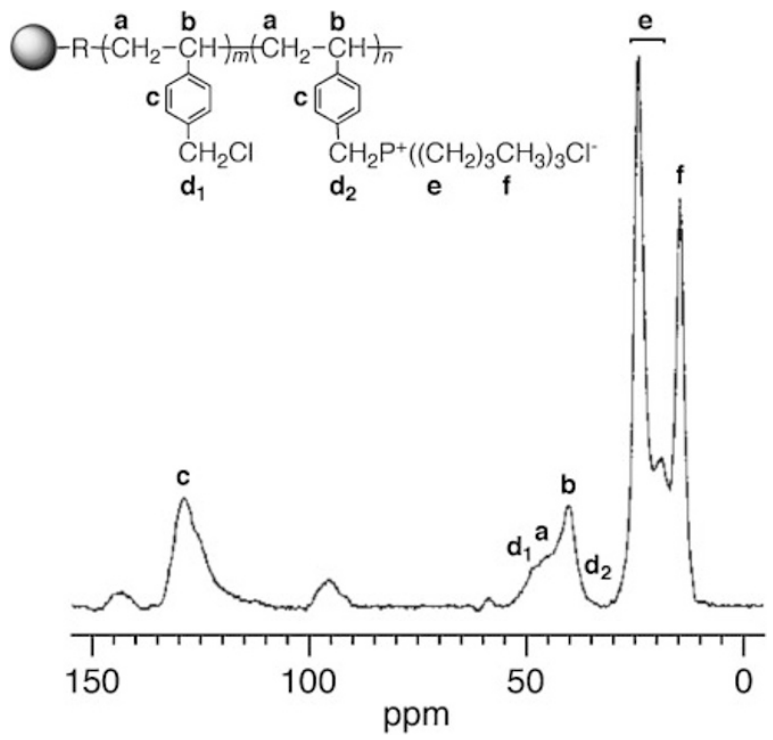

Figure 4. ${ }^{13} \mathrm{C}-\mathrm{CP} / \mathrm{MAS} \mathrm{NMR}$ spectrum of Silica-poly $\left(\mathrm{St}-\mathrm{CH}_{2} \mathrm{P}^{+}(\mathrm{Bu})_{3} \mathrm{Cl}^{-}\right)$ (1).

Figure 5 shows the relationship between the percentage of poly $\left(\mathrm{St}-\mathrm{CH}_{2} \mathrm{Cl}\right)$ grafting onto silica surface and tributylphosphonium group content. The tributylphosphonium group content on silica surface increased with an increase in percentage of poly $\left(\mathrm{St}-\mathrm{CH}_{2} \mathrm{Cl}\right)$ grafting.

\section{Preparation of Silica-poly $\left(\mathrm{St}-\mathrm{CH}_{2} \mathrm{P}^{+}\left(\mathrm{Bu}_{3} \mathrm{Cl}^{-}\right)\right.$(2) by Di- rect Grafting}

Silica-poly $\left(\mathrm{St}_{-} \mathrm{CH}_{2} \mathrm{P}^{+}(\mathrm{Bu})_{3} \mathrm{Cl}^{-}\right)$(2) was prepared by the direct graft polymerization of the corresponding monomer initiated by the system consisting of Silica- $\mathrm{COCCl}_{3}$ and $\mathrm{Mo}(\mathrm{CO})_{6}$. Figure 6 shows the relationship between percentage of poly $\left(\mathrm{St}_{-} \mathrm{CH}_{2} \mathrm{P}^{+}(\mathrm{Bu})_{3} \mathrm{Cl}^{-}\right)$grafting and reaction time. The percentage grafting of poly $\left(\mathrm{St}_{-} \mathrm{CH}_{2} \mathrm{P}^{+}\left(\mathrm{Bu}_{3} \mathrm{Cl}^{-}\right)\right.$onto silica surface increased with progress of the polymerization and reached $22.6 \%$ after $60 \mathrm{~min}$. But the percentage of grafting was 


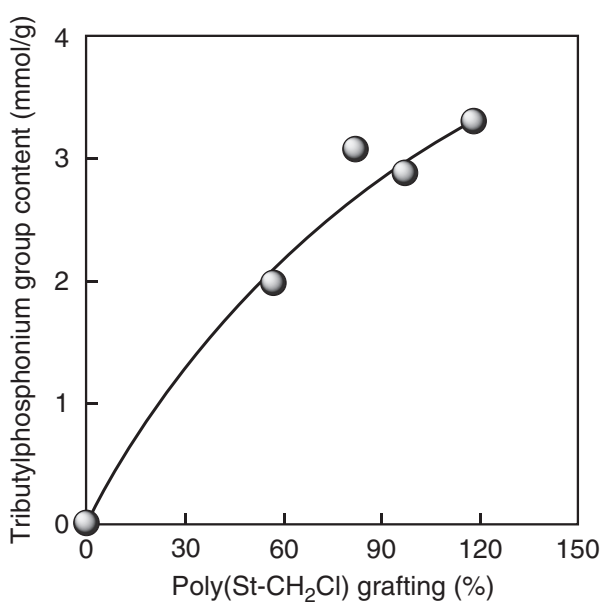

Figure 5. Relationship between the percentage of poly $\left(\mathrm{St}-\mathrm{CH}_{2} \mathrm{Cl}\right)$ grafting onto silica nanoparticle surface and tributylphosphonium group content introduced onto the surface by the treatment with tributylphosphine.

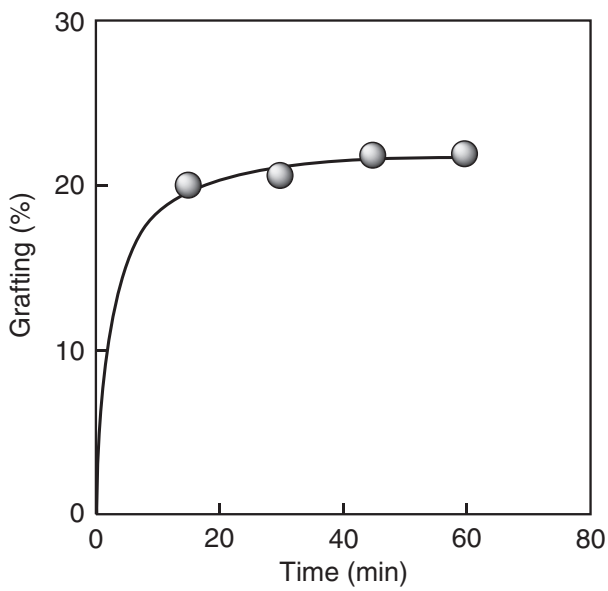

Figure 6. Grafting of poly $\left(\mathrm{St}-\mathrm{CH}_{2} \mathrm{P}^{+}(\mathrm{Bu})_{3} \mathrm{Cl}^{-}\right)$onto silica nanoparticle surface during the polymerization of $\mathrm{St}^{-} \mathrm{CH}_{2} \mathrm{P}^{+}(\mathrm{Bu})_{3} \mathrm{Cl}^{-}$initiated by the system consisting of Silica- $\mathrm{COCCl}_{3}$ and $\mathrm{Mo}(\mathrm{CO})_{6}$. Silica$\mathrm{COCCl}_{3}, \quad 0.20 \mathrm{~g} ; \mathrm{Mo}(\mathrm{CO})_{6}, \quad 0.01 \mathrm{~g} ; \mathrm{St}_{-}-\mathrm{CH}_{2} \mathrm{P}^{+}(\mathrm{Bu})_{3} \mathrm{Cl}^{-}, 0.9 \mathrm{~g}$; DMSO, $10 \mathrm{~mL} ; 70^{\circ} \mathrm{C}$.

smaller than that of Silica-poly $\left(\mathrm{St}-\mathrm{CH}_{2} \mathrm{P}^{+}\left(\mathrm{Bu}_{3} \mathrm{Cl}^{-}\right)\right.$(1). This may be due to the fact that $\mathrm{St}_{-} \mathrm{CH}_{2} \mathrm{P}^{+}(\mathrm{Bu})_{3} \mathrm{Cl}^{-}$has bulky side group.

Mass spectra of thermal decomposition gas of Silicapoly $\left(\mathrm{St}-\mathrm{CH}_{2} \mathrm{P}^{+}(\mathrm{Bu})_{3} \mathrm{Cl}^{-}\right)$(2) at retention time $5.2 \mathrm{~min}$ was also in agreement with that of tributylphosphine. Figure 7 shows ${ }^{13} \mathrm{C}-\mathrm{CP} / \mathrm{MAS} \mathrm{NMR}$ spectrum of Silica-poly(St$\left.\mathrm{CH}_{2} \mathrm{P}^{+}(\mathrm{Bu})_{3} \mathrm{Cl}^{-}\right)$(2). The signals of carbon atoms based on poly $\left(\mathrm{St}-\mathrm{CH}_{2} \mathrm{P}^{+}(\mathrm{Bu})_{3} \mathrm{Cl}^{-}\right)$were observed. Based on the above results, it is concluded that poly $\left(\mathrm{St}-\mathrm{CH}_{2} \mathrm{P}^{+}(\mathrm{Bu})_{3} \mathrm{Cl}^{-}\right)$was also successfully grafted onto silica surface.

Estimation of Antibacterial Activity of Silica-poly(St$\mathrm{CH}_{2} \mathrm{P}^{+}\left(\mathrm{Bu}_{3} \mathrm{Cl}^{-}\right)(\mathbf{1})$

Figure 8 shows the effect of Silica-poly(St$\left.\mathrm{CH}_{2} \mathrm{P}^{+}(\mathrm{Bu})_{3} \mathrm{Cl}^{-}\right)(\mathbf{1})$ (grafting $\left.=142 \%\right)$ on the antibacterial

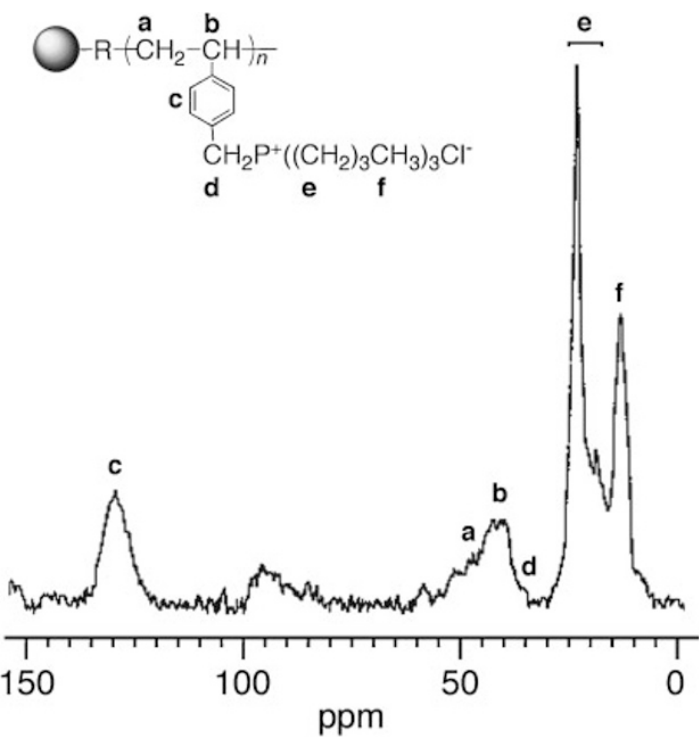

Figure 7. ${ }^{13} \mathrm{C}-\mathrm{CP} / \mathrm{MAS}$ NMR spectrum of Silica-poly $\left(\mathrm{St}-\mathrm{CH}_{2} \mathrm{P}^{+}(\mathrm{Bu})_{3} \mathrm{Cl}^{-}\right)$ (2).

(a)

(b)

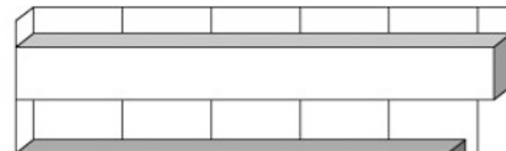

(c)

(d)

(e)

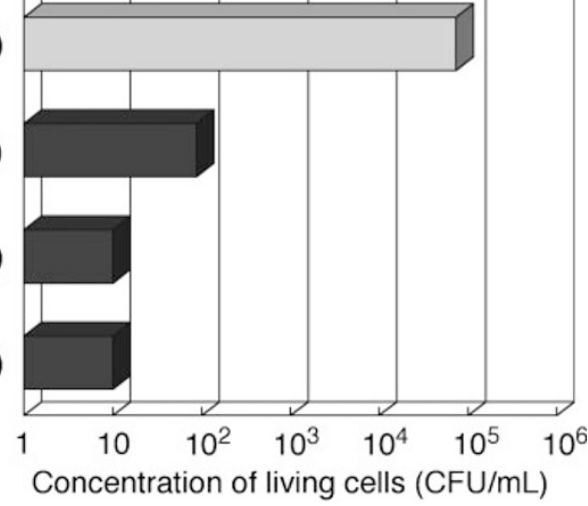

Figure 8. Antibacterial activity of the surface of silicone rubber filled with Silica-poly $\left(\mathrm{St}-\mathrm{CH}_{2} \mathrm{P}^{+}(\mathrm{Bu})_{3} \mathrm{Cl}^{-}\right) \quad(1) \quad$ (grafting = 142\%) against Staphylococcus aureus. (a) cells inoculated, (b) untreated silica $1.0 \mathrm{wt} \%$, (c) Silica-poly $\left(\mathrm{St}-\mathrm{CH}_{2} \mathrm{P}^{+}(\mathrm{Bu})_{3} \mathrm{Cl}^{-}\right)$(1) $0.1 \mathrm{wt} \%$, (d) Silica-poly $\left(\mathrm{St}-\mathrm{CH}_{2} \mathrm{P}^{+}(\mathrm{Bu})_{3} \mathrm{Cl}^{-}\right)$(1) $0.5 \mathrm{wt} \%$, (e) Silica-poly(St$\left.\mathrm{CH}_{2} \mathrm{P}^{+}(\mathrm{Bu})_{3} \mathrm{Cl}^{-}\right)(1) 1.0$ wt \%

activity against Staphylococcus aureus. It was found that the surface of silicone rubber filled with untreated silica shows no antibacterial activity. On the contrary, cells of Staphylococcus aureus decreased from $2.4 \times 10^{5}$ to less than $10 \mathrm{CFU} / \mathrm{mL}$ on silicone rubber filled with $1.0 \mathrm{wt} \%$ of Silica-poly(St$\left.\mathrm{CH}_{2} \mathrm{P}^{+}(\mathrm{Bu})_{3} \mathrm{Cl}^{-}\right)$(1). Even the surface of silicone rubber filled with $0.1 \mathrm{wt} \%$ of Silica-poly $\left(\mathrm{St}-\mathrm{CH}_{2} \mathrm{P}^{+}(\mathrm{Bu})_{3} \mathrm{Cl}^{-}\right)$(1) shows antibacterial activity.

Based on the above results, it was concluded that the surface of silicone rubber filled with Silica-poly $\left(\mathrm{St}-\mathrm{CH}_{2} \mathrm{P}^{+}(\mathrm{Bu})_{3} \mathrm{Cl}^{-}\right)$ (1) shows strong antibacterial activity to Staphylococcus aureus. 
(a)

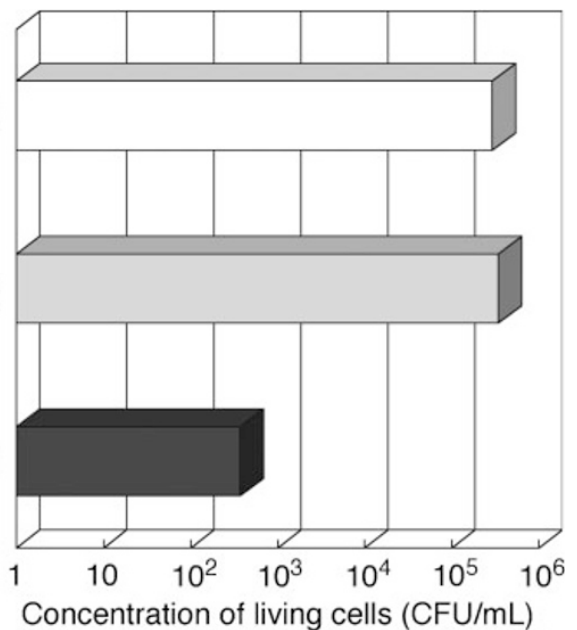

Figure 9. Antibacterial activity of the surface of silicone rubber filled with Silica-poly $\left(\mathrm{St}-\mathrm{CH}_{2} \mathrm{P}^{+}(\mathrm{Bu})_{3} \mathrm{Cl}^{-}\right.$) (2) (grafting $=22.6 \%$ ) against Staphylococcus aureus. (a) cells inoculated, (b) untreated silica 1.0 wt \%, (c) Silica-poly $\left(\mathrm{St}-\mathrm{CH}_{2} \mathrm{P}^{+}(\mathrm{Bu})_{3} \mathrm{Cl}^{-}\right)(2) 1.0 \mathrm{wt} \%$.

\section{(A) Escherichia coli}

(a)

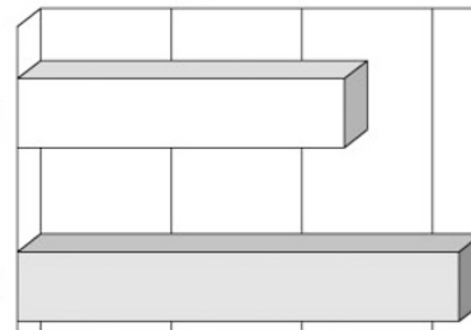

(c)

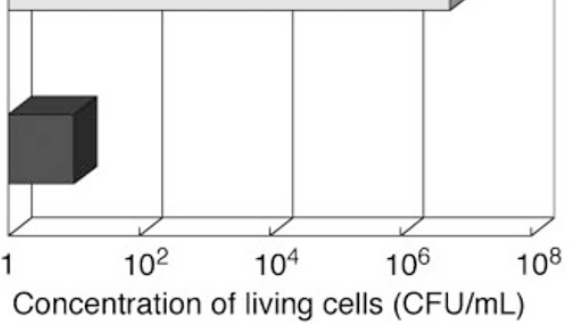

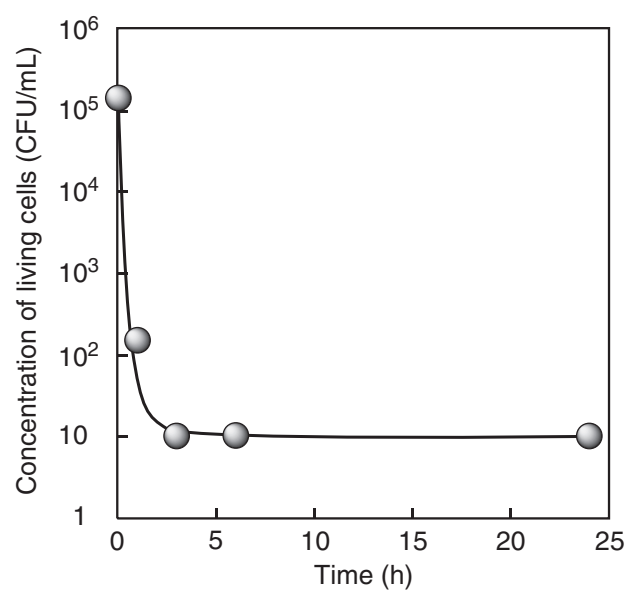

Figure 11. Relationship between contacting time and concentration of living cells of Staphylococcus aureus on the surface of silicone rubber filled with $1.0 \mathrm{wt} \%$ of Silica-poly $\left(\mathrm{St}-\mathrm{CH}_{2} \mathrm{P}^{+}(\mathrm{Bu})_{3} \mathrm{Cl}^{-}\right)$(1) (grafting $=142 \%$ ).

(B) Pseudomonas aeruginosa

(a)

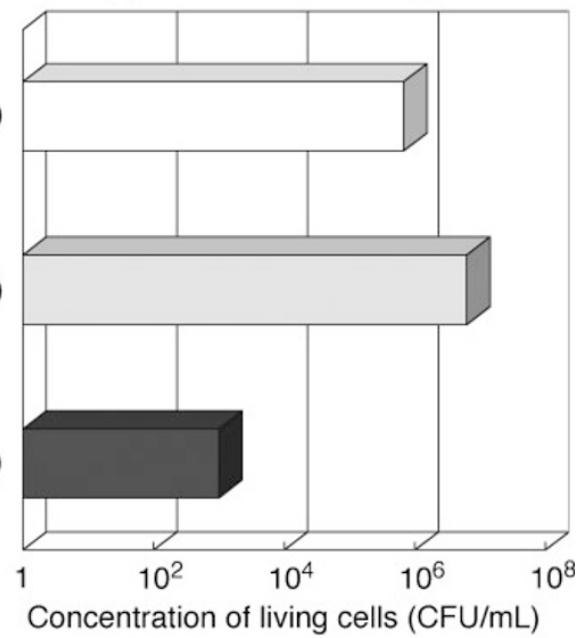

Figure 10. Antibacterial activity of the surface of silicone rubber filled with Silica-poly $\left(\mathrm{St}-\mathrm{CH}_{2} \mathrm{P}^{+}(\mathrm{Bu})_{3} \mathrm{Cl}^{-}\right)(\mathbf{1})(\mathrm{grafting}=142 \%)$ against $(\mathrm{A})$ Escherichia coli and (B) Pseudomonas aeruginosa. (a) cells inoculated, (b) untreated silica $1.0 \mathrm{wt} \%$, (c) Silica-poly $\left(\mathrm{St}_{-} \mathrm{CH}_{2} \mathrm{P}^{+}\left(\mathrm{Bu}_{3} \mathrm{Cl}^{-}\right)(1) 1.0 \mathrm{wt} \%\right.$.

Estimation of Antibacterial Activity of Silica-poly(St$\mathrm{CH}_{2} \mathbf{P}^{+}\left(\mathrm{Bu}_{3} \mathrm{Cl}^{-}\right)(2)$

Figure 9 shows the effect of Silica-poly(St$\left.\mathrm{CH}_{2} \mathrm{P}^{+}(\mathrm{Bu})_{3} \mathrm{Cl}^{-}\right)(2)$ (grafting $=22.6 \%$ ) on the antibacterial activity to Staphylococcus aureus. Figure 9 clearly shows that the surface of silicone rubber filled with $1.0 \mathrm{wt} \%$ of Silicapoly $\left(\mathrm{St}-\mathrm{CH}_{2} \mathrm{P}^{+}(\mathrm{Bu})_{3} \mathrm{Cl}^{-}\right)$(2) also shows antibacterial activity to Staphylococcus aureus.

Antibacterial Activity of the Surface of Silicone Rubber Filled with Silica-poly $\left(\mathrm{St}-\mathrm{CH}_{2} \mathrm{P}^{+}\left(\mathrm{Bu}_{3} \mathrm{Cl}^{-}\right)\right.$(1) against Several Bacteria

Figure 10 shows the antibacterial activity of the surface of silicone rubber filled with Silica-poly $\left(\mathrm{St}-\mathrm{CH}_{2} \mathrm{P}^{+}(\mathrm{Bu})_{3} \mathrm{Cl}^{-}\right)(\mathbf{1})$ (grafting $=142 \%$ ) against $(\mathrm{A})$ Escherichia coli and (B) Pseudomonas aeruginosa. It was found that the surface of silicone rubber filled with $1.0 \mathrm{wt} \%$ of Silica-poly(St$\left.\mathrm{CH}_{2} \mathrm{P}^{+}(\mathrm{Bu})_{3} \mathrm{Cl}^{-}\right)$(1) also shows strong antibacterial activity against Escherichia coli and Pseudomonas aeruginosa.

Figure 11 shows the relationship between contacting time and concentration of living cells of Staphylococcus aureus on silicone rubber filled with $1.0 \mathrm{wt} \%$ of Silica-poly(St$\left.\mathrm{CH}_{2} \mathrm{P}^{+}(\mathrm{Bu})_{3} \mathrm{Cl}^{-}\right)$(1) (grafting $=142 \%$ ). It was found that the concentration of living cells decreased from $1.4 \times 10^{5}$ to less than $10 \mathrm{CFU} / \mathrm{mL}$ even after $3 \mathrm{~h}$. The result suggests that the surface of silicone rubber filled with $1.0 \%$ of Silica-poly(St$\left.\mathrm{CH}_{2} \mathrm{P}^{+}(\mathrm{Bu})_{3} \mathrm{Cl}^{-}\right)(\mathbf{1})$ effectively inhibited the proliferation of bacteria.

Antibacterial Activity of the Surface of PolySt Film Filled with Silica-poly $\left(\mathrm{St}-\mathrm{CH}_{2} \mathrm{P}^{+}\left(\mathrm{Bu}_{3} \mathrm{Cl}^{-}\right)\right.$(1)

Figure 12 shows the antibacterial activity of the surface 
(a)

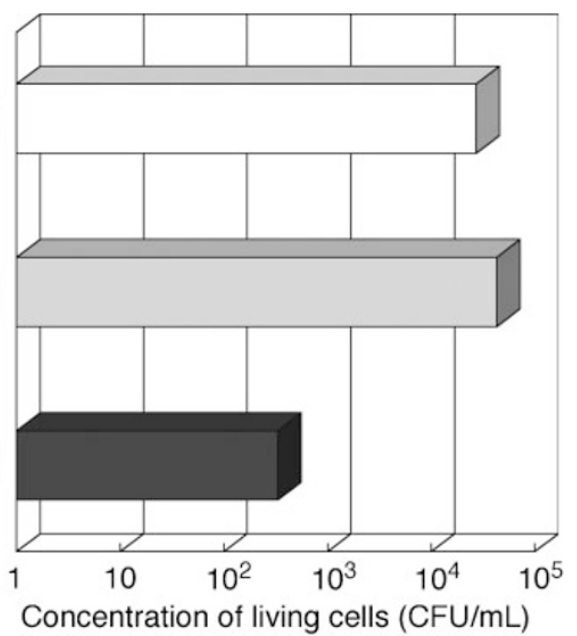

Figure 12. Antibacterial activity of the surface of polySt film filled with Silicapoly $\left(\mathrm{St}-\mathrm{CH}_{2} \mathrm{P}^{+}(\mathrm{Bu})_{3} \mathrm{Cl}^{-}\right)(1)$ (grafting $=91 \%$ ) against Staphylococcus aureus. (a) cells inoculated, (b) untreated silica $1.0 \mathrm{wt} \%$, (c) Silica-poly $\left(\mathrm{St}-\mathrm{CH}_{2} \mathrm{P}^{+}(\mathrm{Bu})_{3} \mathrm{Cl}^{-}\right)$(1) $1.0 \mathrm{wt} \%$.

of polySt film filled with $1.0 \mathrm{wt} \%$ of Silica-poly(St$\left.\mathrm{CH}_{2} \mathrm{P}^{+}(\mathrm{Bu})_{3} \mathrm{Cl}^{-}\right)(\mathbf{1})$ (grafting $=91 \%$ ) against Staphylococcus aureus. It was found that the surface of polySt filled with Silica-poly $\left(\mathrm{St}-\mathrm{CH}_{2} \mathrm{P}^{+}(\mathrm{Bu})_{3} \mathrm{Cl}^{-}\right)(\mathbf{1})$ inhibited the proliferation of Staphylococcus aureus, and the living cells decreased from $4.3 \times 10^{4}$ to $3.3 \times 10^{2} \mathrm{CFU} / \mathrm{mL}$. It is concluded that Silicapoly $\left(\mathrm{St}-\mathrm{CH}_{2} \mathrm{P}^{+}(\mathrm{Bu})_{3} \mathrm{Cl}^{-}\right)(\mathbf{1})$ can be applied as an antibacterial filler not only silicone rubber but also polySt.

\section{Antibacterial Activity of the Surface of Paints Filled with} Silica-poly $\left(\mathrm{St}-\mathrm{CH}_{2} \mathrm{P}^{+}\left(\mathrm{Bu}_{3} \mathrm{Cl}^{-}\right)\right.$(1)

Figure 13 shows the antibacterial activity of the surface of (A) water paint (acrylic emulsion type) and (B) oil paint (acrylic urethane type) filled with $2.0 \mathrm{wt} \%$ of Silica-poly(St-
$\left.\mathrm{CH}_{2} \mathrm{P}^{+}(\mathrm{Bu})_{3} \mathrm{Cl}^{-}\right)(\mathbf{1})$ (grafting $=145 \%$ ) against Escherichia coli, respectively. It was found that the surface of water paint filled with Silica-poly $\left(\mathrm{St}-\mathrm{CH}_{2} \mathrm{P}^{+}\left(\mathrm{Bu}_{3} \mathrm{Cl}^{-}\right)\right.$(1) inhibited the proliferation of Escherichia coli, and the living cells decreased from $1.6 \times 10^{7}$ to $8.9 \times 10^{3} \mathrm{CFU} / \mathrm{mL}$. In addition, it became apparent that the surface of oil paint filled with Silica-poly(St$\left.\mathrm{CH}_{2} \mathrm{P}^{+}(\mathrm{Bu})_{3} \mathrm{Cl}^{-}\right)$(1) also inhibited the proliferation of Escherichia coli.

Stability of Antibacterial Activity of the Surface of Silicone Rubber Filled with Silica-poly $\left(\mathrm{St}-\mathrm{CH}_{2} \mathrm{P}^{+}\left(\mathrm{Bu}_{3} \mathrm{Cl}^{-}\right)\right.$(1)

The decrease of antibacterial activity based on the elimination from silicone rubber filled with Silica-poly(St$\left.\mathrm{CH}_{2} \mathrm{P}^{+}(\mathrm{Bu})_{3} \mathrm{Cl}^{-}\right)$(1) by boiling in water was estimated. Figure 14 shows the antibacterial activity of the surface of silicone rubber filled with (c) Silica-poly $\left(\mathrm{St}-\mathrm{CH}_{2} \mathrm{P}^{+}(\mathrm{Bu})_{3} \mathrm{Cl}^{-}\right)$ (1) and (d) free poly $\left(\mathrm{St}-\mathrm{CH}_{2} \mathrm{P}^{+}(\mathrm{Bu})_{3} \mathrm{Cl}^{-}\right)$against Escherichia coli after boiling in water. The amount of free poly(St$\left.\mathrm{CH}_{2} \mathrm{P}^{+}(\mathrm{Bu})_{3} \mathrm{Cl}^{-}\right)$filled into silicone rubber is exactly equal to that of grafted poly $\left(\mathrm{St}-\mathrm{CH}_{2} \mathrm{P}^{+}(\mathrm{Bu})_{3} \mathrm{Cl}^{-}\right)$on the silica surface.

Before the boiling in water (boiling for $0 \mathrm{~h}$ ), the surface of silicone rubbers filled with poly $\left(\mathrm{St}-\mathrm{CH}_{2} \mathrm{P}^{+}(\mathrm{Bu})_{3} \mathrm{Cl}^{-}\right)$and free poly $\left(\mathrm{St}-\mathrm{CH}_{2} \mathrm{P}^{+}(\mathrm{Bu})_{3} \mathrm{Cl}^{-}\right)$shows strong antibacterial activity. However, the antibacterial activity of the surface of silicone rubber filled with free poly $\left(\mathrm{St}-\mathrm{CH}_{2} \mathrm{P}^{+}(\mathrm{Bu})_{3} \mathrm{Cl}^{-}\right)$dramatically decreased even after boiling for $1 \mathrm{~h}$ and lost the antibacterial activity after boiling for $24 \mathrm{~h}$ because of elimination of poly(St$\left.\mathrm{CH}_{2} \mathrm{P}^{+}(\mathrm{Bu})_{3} \mathrm{Cl}^{-}\right)$from silicone rubber surface.

On the contrary, the surface of silicone rubber filled with Silica-poly $\left(\mathrm{St}-\mathrm{CH}_{2} \mathrm{P}^{+}(\mathrm{Bu})_{3} \mathrm{Cl}^{-}\right)(\mathbf{1})$ was maintained antibacterial activity even after boiling for $24 \mathrm{~h}$. The results clearly show that by grafting of poly $\left(\mathrm{St}-\mathrm{CH}_{2} \mathrm{P}^{+}(\mathrm{Bu})_{3} \mathrm{Cl}^{-}\right)$onto silica surface, the elution of $\operatorname{poly}\left(\mathrm{St}-\mathrm{CH}_{2} \mathrm{P}^{+}\left(\mathrm{Bu}_{3} \mathrm{Cl}^{-}\right)\right.$from silicone rubber was completely inhibited because of an anchor effect of silica nanoparticle.
(A) Water paint

(a)

(b)

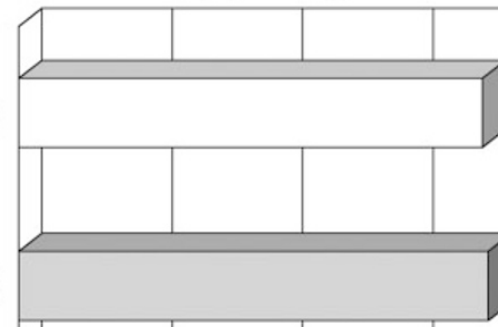

(c)

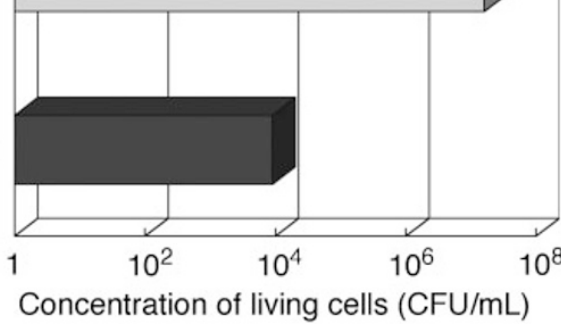

(a)

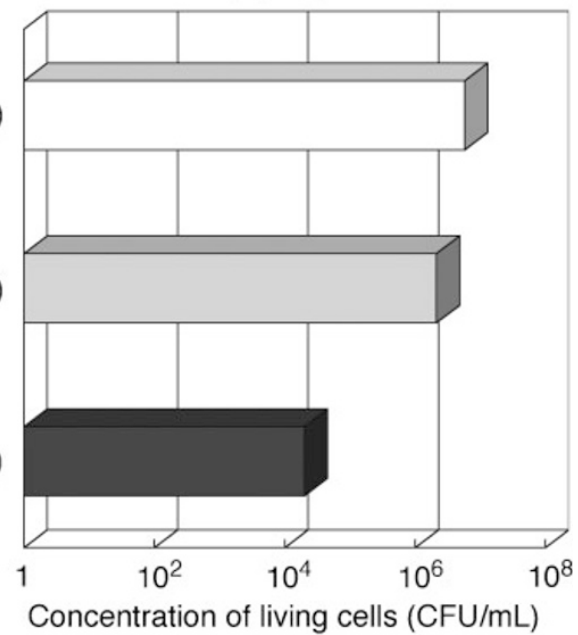

Figure 13. Antibacterial activity of $(\mathrm{A})$ water paint (acrylic emulsion type) and (B) oil paint (acrylic urethane type) filled with $\mathrm{Silica}-\mathrm{poly}\left(\mathrm{St}-\mathrm{CH}_{2} \mathrm{P}^{+}(\mathrm{Bu})_{3} \mathrm{Cl}^{-}\right)(\mathbf{1})$ (grafting $=145 \%$ ) against Escherichia coli. (a) cells inoculated, (b) untreated silica $1.0 \mathrm{wt} \%$, (c) Silica-poly $\left(\mathrm{St}^{-} \mathrm{CH}_{2} \mathrm{P}^{+}(\mathrm{Bu})_{3} \mathrm{Cl}^{-}\right)(\mathbf{1}) 1.0$ wt $\%$. 
(c)

(a)

(b)

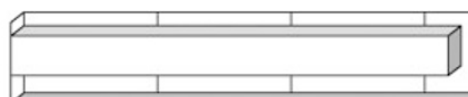

h

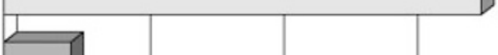

(d)

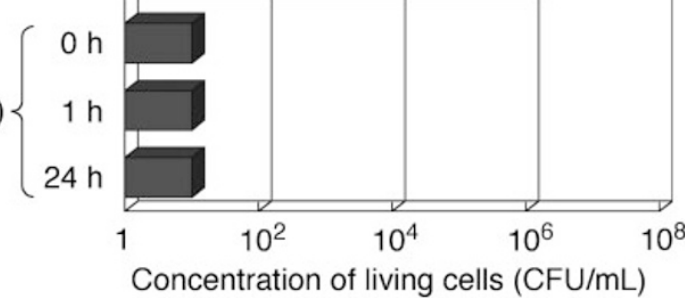

Figure 14. Antibacterial activity of the surface of silicone rubber filled with free poly $\left(\mathrm{St}_{-} \mathrm{CH}_{2} \mathrm{P}^{+}(\mathrm{Bu})_{3} \mathrm{Cl}^{-}\right)$and Silica-poly(St$\left.\mathrm{CH}_{2} \mathrm{P}^{+}(\mathrm{Bu})_{3} \mathrm{Cl}^{-}\right)(\mathbf{1})$ (grafting $=142 \%$ ) against Escherichia coli after boiling in water. (a) cells inoculated, (b) untreated silica $1.0 \mathrm{wt} \%$, (c) free poly $\left(\mathrm{St}-\mathrm{CH}_{2} \mathrm{P}^{+}(\mathrm{Bu})_{3} \mathrm{Cl}^{-}\right.$), (d) Silica-poly(St$\left.\mathrm{CH}_{2} \mathrm{P}^{+}(\mathrm{Bu})_{3} \mathrm{Cl}^{-}\right)(1) 1.0 \mathrm{wt} \%$.

\section{CONCLUSIONS}

1. Antibacterial polymer, poly $\left(\mathrm{St}-\mathrm{CH}_{2} \mathrm{P}^{+}(\mathrm{Bu})_{3} \mathrm{Cl}^{-}\right)$, was successfully grafted by two methods: one is treatment of poly $\left(\mathrm{St}-\mathrm{CH}_{2} \mathrm{Cl}\right)$-grafted silica with tributylphosphine and the other is direct grafting of poly(St$\left.\mathrm{CH}_{2} \mathrm{P}^{+}(\mathrm{Bu})_{3} \mathrm{Cl}^{-}\right)$by radical graft polymerization of the corresponding monomer.

2. The surfaces of silicone rubber, polystyrene film, and paints, filled with Silica-poly $\left(\mathrm{St}_{-} \mathrm{CH}_{2} \mathrm{P}^{+}(\mathrm{Bu})_{3} \mathrm{Cl}^{-}\right)$ showed strong antibacterial activity against various bacteria.

3. The surface of silicone rubber filled with Silica-poly(St-
$\left.\mathrm{CH}_{2} \mathrm{P}^{+}(\mathrm{Bu})_{3} \mathrm{Cl}^{-}\right)$was maintained antibacterial activity even after boiling for $24 \mathrm{~h}$ in water because of an anchor effect of silica nanoparticle.

Received: February 1, 2009

Accepted: May 28, 2009

Published: July 9, 2009

\section{REFERENCES}

1. J. P. Blits and C. B. Little, "Fundamental and Applied Aspects of Chemically Modified Surfaces," N. Tsubokawa, Ed, The Royal Soc. Chem., CRC Press, London, 1999, p. 36.

2. N. Tsubokawa, Bull. Chem. Soc. Jpn., 75, 2115 (2002).

3. N. Tsubokawa, Polym. J., 37, 637 (2005).

4. R. Yokoyama, S. Suzuki, K. Shirai, T. Yamauchi, N. Tsubokawa, and M. Tsuchimochi, Eur. Polym. J., 42, 3221 (2006).

5. M. Ukaji, M. Takamura, K. Shirai, W. Gang, T. Yamauchi, and N. Tsubokawa, Polym. J., 40, 607 (2008).

6. N. Tsubokawa, Polym. J., 39, 983 (2007).

7. Y. Shirai and N. Tsubokawa, React. Funct. Polym., 32, 153 (1997).

8. G. Wei, S. Saitoh, H. Saitoh, K. Fujiki, T. Yamauchi, and N. Tsubokawa, Polymer, 45, 8723 (2004).

9. Y. Nakagawa, N. Dohi, T. Tawaratani, and I. Shibasaki, J. Antibact. Antifung. Agents, 11, 263 (1983).

10. T. Ikeda, H. Yamaguchi, and S. Tazuke, J. Bioact. Compat. Polym., 1, 301 (1986).

11. a) A. Kanazawa, T. Ikeda, and T. Endo, J. Polym. Sci., Part A: Polym. Chem., 31, 335 (1993).

b) A. Kanazawa, T. Ikeda, and T. Endo, J. Polym. Sci., Part A. Polym. Chem., 31, 1441 (1993).

c) A. Kanazawa, T. Ikeda, and T. Endo, J. Polym. Sci., Part A: Polym. Chem., 31, 1467 (1993).

d) A. Kanazawa, T. Ikeda, and T. Endo, J. Polym. Sci., Part A: Polym. Chem., 31, 2873 (1993).

e) A. Kanazawa, T. Ikeda, and T. Endo, J. Polym. Sci., Part A: Polym. Chem., 31, 3003 (1993).

f) A. Kanazawa, T. Ikeda, and T. Endo, J. Polym. Sci., Part A: Polym. Chem., 31, 3031 (1993).

12. R. Yamashita, Y. Takeuchi, H. Kikuchi, K. Shirai, T. Yamauchi, and N. Tsubokawa, Polym. J., 38, 844 (2006). 